\title{
A New High-Speed Droplet-Real-Time Polymerase Chain Reaction Method Can Detect Bovine Respiratory Syncytial Virus in Less than 10 Min
}

\author{
Masayuki UEHARA ${ }^{1,2) *}$, Kazuyuki MATSUDA ${ }^{3)}$, Mitsutoshi SUGANO ${ }^{3)}$ and Takayuki HONDA ${ }^{1,3)}$ \\ 1)Division of Medical Seeds Promotion, Shinshu University School of Medicine, 3-1-1 Asahi, Matsumoto 390-8621, Japan \\ ${ }^{2)}$ Core Technology Development Center, Corporate Research and Development Division, Seiko Epson Corporation, 281 Fujimi, \\ Fujimi-machi, Suwa-gun, Nagano 399-0293, Japan \\ 3) Department of Laboratory Medicine, Shinshu University Hospital, 3-1-1 Asahi, Matsumoto 390-8621, Japan
}

(Received 16 July 2013/Accepted 14 November 2013/Published online in J-STAGE 28 November 2013)

ABSTRACT. The polymerase chain reaction (PCR) has been widely used for diagnosis of infectious diseases of domestic animals. Rapid detection of respiratory pathogens of cattle is useful for making therapeutic decisions. Therefore, we developed a new genetic-based method called droplet-real-time PCR, which can detect bovine respiratory syncytial virus (BRSV) within 10 min. Our droplet-real-time PCR markedly reduced the reaction time of reverse transcription-PCR while maintaining the same sensitivity as conventional real-time PCR, and it can be used as a rapid assay for detection of BRSV. Furthermore, our method is potentially applicable for rapid diagnosis of almost all infectious diseases, including highly pathogenic avian influenza virus.

KEY WORDS: bovine respiratory syncytial virus, domestic animal, droplet-real-time PCR, infectious disease.

doi: 10.1292/jvms.13-0357; J. Vet. Med. Sci. 76(3): 477-480, 2014

Rapid and accurate diagnosis of infectious diseases of domestic animals is especially critical for preventing disease spread. Although nucleic acid amplification diagnostic tests using the real-time PCR [6] are widely used to check infectious diseases [13], real-time PCR takes a considerable amount of time to obtain the results (at least several hours). A more rapid method is desirable for treatment and control of the infectious diseases. Therefore, we have developed a novel real-time PCR method that can be completed in a reaction tube within $10 \mathrm{~min}$. This method utilizes two heating blocks at different temperatures - a high-temperature block (denaturation) and a low-temperature block (annealing/extension) - that can quickly alter the temperature of the reaction mixture in a newly developed PCR machine. We call this novel high-speed PCR method "droplet-real-time PCR."

Here, we applied droplet-real-time PCR to detect BRSV, which is an RNA virus classified as a pneumovirus belonging to the paramyxovirus family [12]. BRSV is indigenous in the cattle population and is common around the world. Bovine respiratory disease complex (BRD), which is frequently caused by BRSV infection of the lower respiratory tract, is a major problem in the cattle industry causing huge economic losses. Therefore, research on BRD has been a longstanding global priority. BRD accompanied with irreversible lung damage by BRSV will make livestock more susceptible to other bovine diseases and will reduce economic returns for

\footnotetext{
*Correspondence to: Uehara, M., Division of Medical Seeds Promotion, Shinshu University School of Medicine, 3-1-1 Asahi, Matsumoto 390-8621, Japan. e-mail: mauehara@shinshu-u.ac.jp (C)2014 The Japanese Society of Veterinary Science
}

This is an open-access article distributed under the terms of the Creative Commons Attribution Non-Commercial No Derivatives (by-ncnd) License $<$ http://creativecommons.org/licenses/by-nc-nd/3.0/>. farmers $[2,4,5]$. For diagnosis of BRSV, virus isolation, immunohistochemistry/immunofluorescence antibody testing or reverse transcription (RT)-PCR procedures are necessary $[1,14]$, and these tests are both expensive and time consuming. The sensitivity of immunohistochemistry/immunofluorescence antibody testing is not high, and antibodies specific for viral protein are required. On the other hand, RT-PCR methods require a longer operation time and expensive reagents. The present study was performed to develop a rapid and cost-effective real-time RT-PCR method for detecting pathogens in animal samples.

Figure 1A shows a droplet-real-time PCR device with reaction tubes held in the holders, consisting of main and driving units. Figure $1 \mathrm{~B}$ shows a cross-sectional view of the main unit along the line A'-A" in Fig. 1A. The main unit is composed of 8 holders and the first and second heating blocks. The first and second heating blocks are able to heat predetermined portions of a reaction tube. The driving unit rotates the whole holder and changes the sample in the tube from the first heating block to the second or from the second to the first. The drive shaft of this device is perpendicular to the longitudinal direction of the holder, and the reaction tube in the holder is turned upside down around the drive shaft as the rotational axis. The reaction tube is filled with silicon oil. A volume of $1 \mu l$ of reaction mixture is introduced into the reaction tube with a micropipette (Fig. 1C) and is held inside the silicon oil as a spherical droplet in an internal diameter of $2 \mathrm{~mm}$ and a length of $25 \mathrm{~mm}$. The silicon oil has a specific gravity, and the reaction mixture moves to the lowest part of the tube by gravitational force (Fig. 1C).

Droplet-real-time PCR also includes a fluorescence detector (Fig. 1A) and can also be used for conventional real-time PCR. The single fluorescence detector moves along the slide to detect appropriate fluorescence through the measurement windows of the second heating block on the lower tempera- 


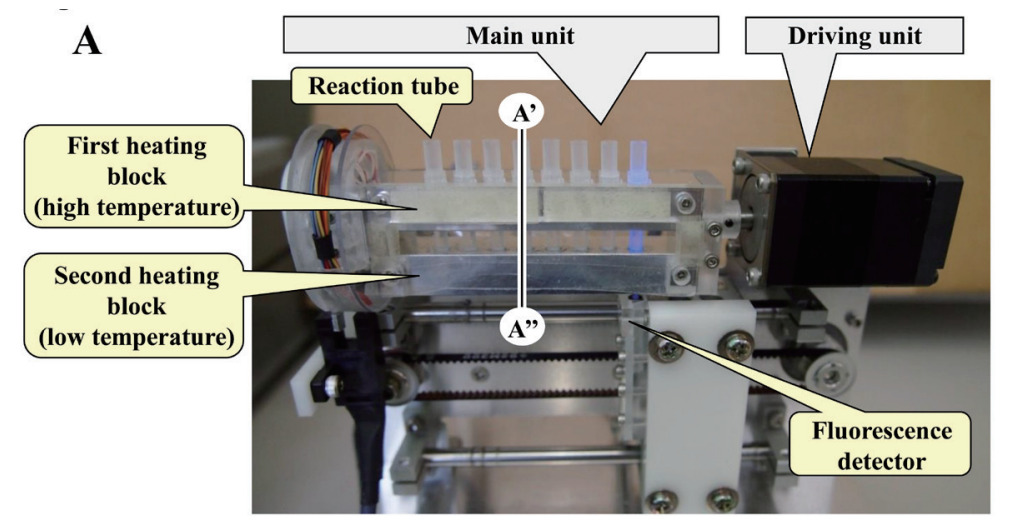

B

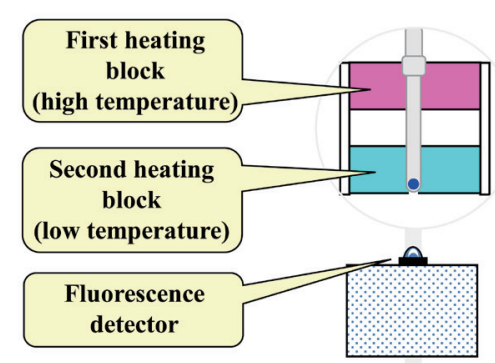

C
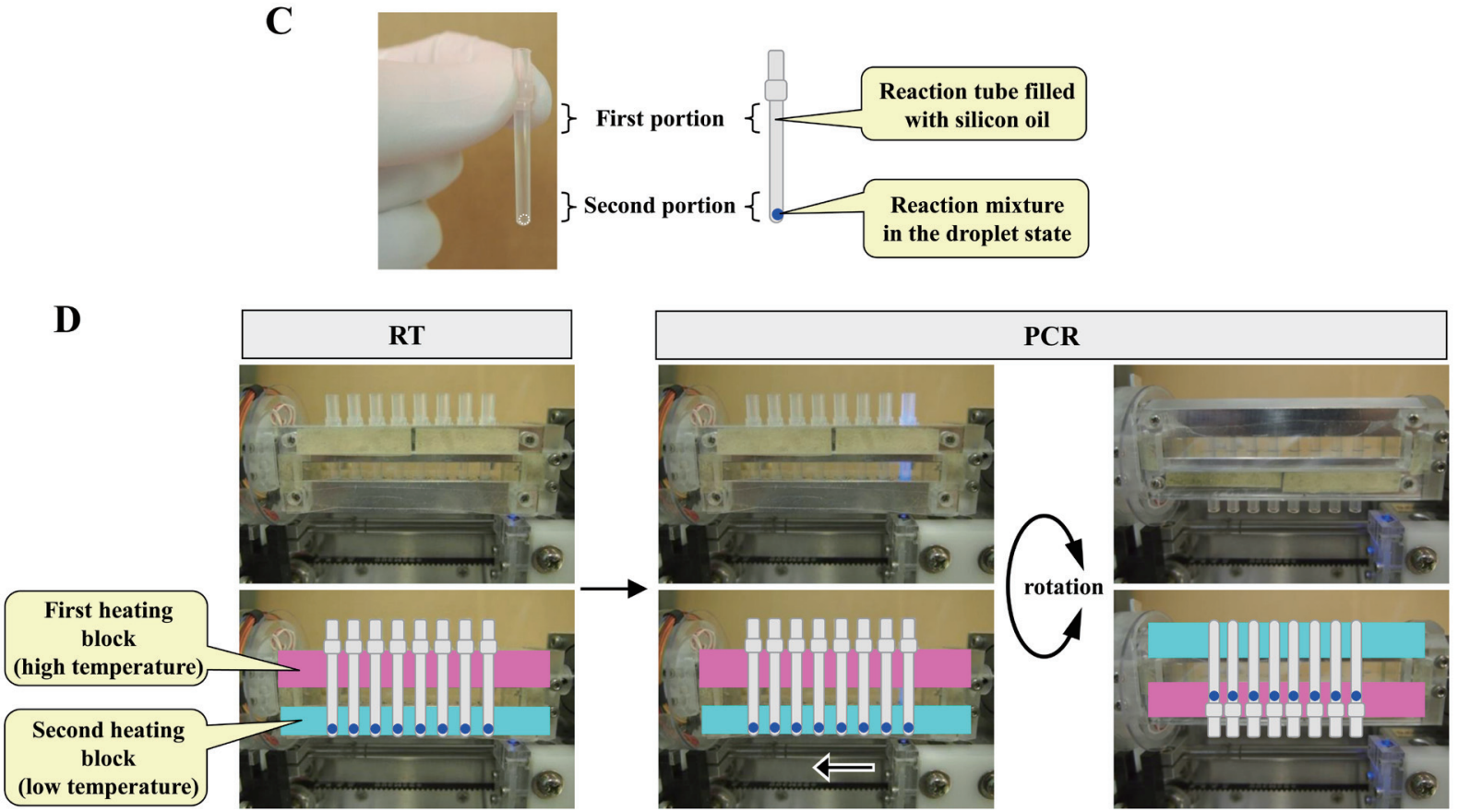

Fig. 1. Diagram of the droplet-real-time PCR device. (A) Lateral view and (B) schema of vertical cross-sectional view. (C) A photograph and a schematic image of the reaction tube. (D) Photographs and schemas during droplet-real-time RT-PCR.

Table 1. Reaction conditions of the new droplet-real-time PCR and conventional real-time PCR

\begin{tabular}{|c|c|c|c|c|c|c|c|}
\hline \multicolumn{4}{|c|}{ The new droplet-real-time PCR } & \multicolumn{4}{|c|}{ Conventional real-time PCR } \\
\hline Step & Temperature & Time & Cycles & Step & Temperature & Time & Cycles \\
\hline cDNA synthesis & $50^{\circ} \mathrm{C}$ & $30 \mathrm{~s}$ & 1 & cDNA synthesis & $50^{\circ} \mathrm{C}$ & $15 \mathrm{~min}$ & 1 \\
\hline Inactivation of SuperScript III & $98^{\circ} \mathrm{C}$ & $10 \mathrm{~s}$ & 1 & Inactivation of SuperScript III & $95^{\circ} \mathrm{C}$ & $2 \min$ & 1 \\
\hline Denaturing & $98^{\circ} \mathrm{C}$ & $3 \mathrm{~s}$ & \multirow{2}{*}{50} & Denaturing & $95^{\circ} \mathrm{C}$ & $15 \mathrm{~s}$ & \multirow{2}{*}{50} \\
\hline Annealing / Extension & $57^{\circ} \mathrm{C}$ & $6 \mathrm{~s}$ & & Annealing / Extension & $55^{\circ} \mathrm{C}$ & $30 \mathrm{~s}$ & \\
\hline Total-time & \multicolumn{3}{|c|}{$9 \min 55 \mathrm{~s}$} & Total-time & \multicolumn{3}{|c|}{$80 \mathrm{~min}$} \\
\hline Machine & \multicolumn{3}{|c|}{ Droplet-real-time PCR machine } & Machine & \multicolumn{3}{|c|}{ StepOnePlus Real-Time PCR } \\
\hline
\end{tabular}

ture side (annealing/extension step) (Fig. 1D). The first heating block heats the first portion of the reaction tube to $98^{\circ} \mathrm{C}$, and the second heating block heats the second portion to $50^{\circ} \mathrm{C}$ (Fig. 1C and 1D). However, it improves the efficiency of droplet-real-time PCR to heat the second portion to $57^{\circ} \mathrm{C}$, and we use 50 cycles of $98^{\circ} \mathrm{C}$ for $3 \mathrm{sec}$ in the first portion and $57^{\circ} \mathrm{C}$ for $6 \mathrm{sec}$ in the second portion. The fluorescent signals are monitored after each annealing/extension step. 
Conventional real-time PCR by SrepOnePlus (Life Technologies)

A

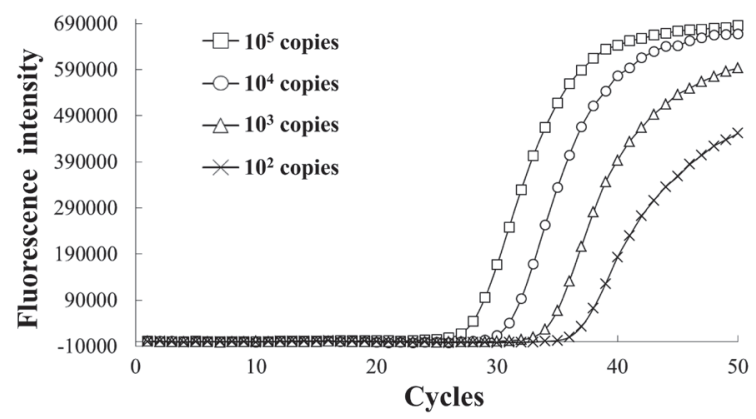

C

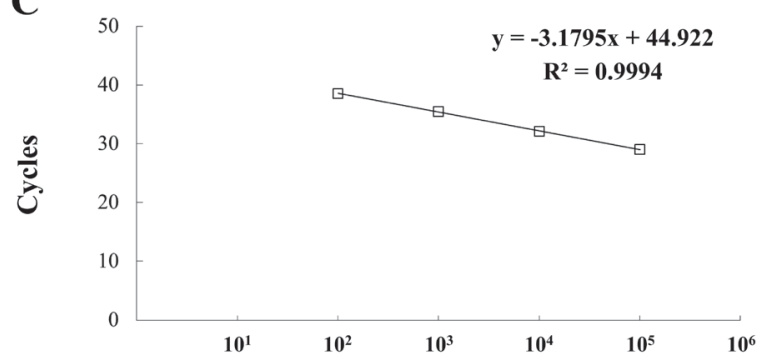

Newly droplet-real-time PCR by droplet-real-time PCR machin (SEIKO EPSON)

$\mathbf{B}$

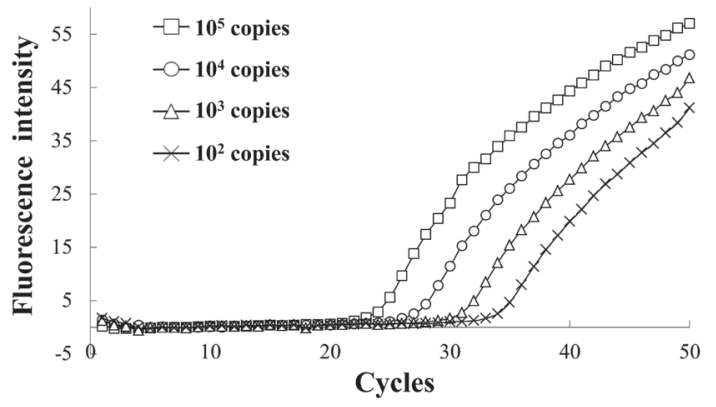

D

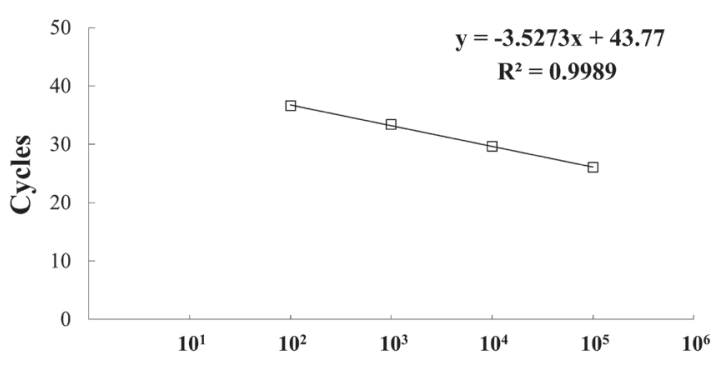

$\mathbf{E}$

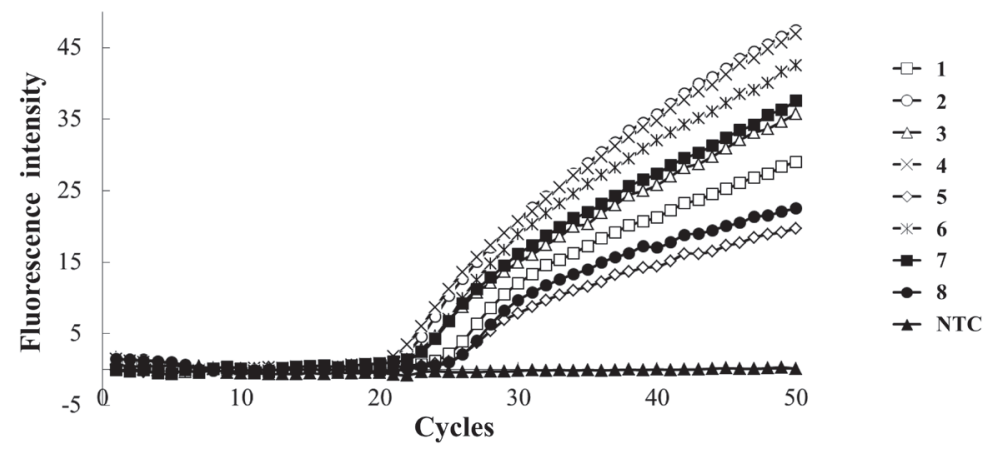

Fig. 2. (A-D) Reactivities of conventional real-time PCR and droplet-real-time PCR. Amplification plots (A and B) were obtained using 10 -fold dilutions of plasmids $\left(10^{2}-10^{5}\right.$ copies) including 138 base pairs of the BRSV nucleocapsid protein $(\mathrm{N})$ gene. Standard curves were constructed from the amplification plots (C and D). (E) Reactivities of 8 BRSV-positive samples by droplet-real-time PCR. All 8 samples were positive for BRSV by droplet-real-time PCR, and the samples without BRSV were negative.

This droplet-real-time PCR can shorten the cycle time due to the simplicity of the device, and real-time PCR test can be performed within $10 \mathrm{~min}$.

To compare the reactivity between droplet-real-time PCR and the conventional procedure, we examined the amplification plots using the BRSV primers and probe.

Total RNA was extracted from nasal swab samples (provided by the Nagano Prefectural Matsumoto Livestock Hygiene Service Center) suspended in diluents using a QIAamp viral RNA mini kit (Qiagen, Valencia, CA, U.S.A.) according to the manufacturer's protocol. The primers and TaqMan probe, which was used in real-time RT-PCR to detect BRSV, were 5'-GGTCAAACTAAATGACACTTTCAACAAG-3' (forward) and 5'-AGCATACCACACAACTTATTGAGATG-3' (reverse), 5'-FAM-TAGTACAGGTGACAACATTGBHQ-3' [9]. The droplet-real-time RT-PCR mixture contained RNA, SuperScript III/Platinum Taq Mix (Life Technologies, Grand Island, NY, U.S.A.), $5 \times$ reaction buffer, $1.6 \mu \mathrm{mol} / l$ of each primer and $0.4 \mu \mathrm{mol} / l$ of TaqMan probe in a total volume of $10 \mu \mathrm{l}$. Aliquots of $1 \mu \mathrm{l}$ of the reaction mixture were used for droplet-real-time PCR (Seiko Epson, Nagano, Japan), and $25 \mu l$ of the same mixture was used for conventional real-time PCR (Life Technologies, Carlsbad, CA, U.S.A.). Reaction conditions are described in Table 1. Amplification plots were obtained using 10-fold dilutions of plasmids $\left(10^{2}-10^{5}\right.$ copies $)$ carrying the 138 base pairs 
of the BRSV nucleocapsid protein (N) gene (TaKaRa Bio, Yokkaichi, Japan). All experimental procedures were carried out in accordance with the regulations of animal experimentation of Shinshu University.

The reaction time of droplet-real-time PCR was $10 \mathrm{~min}$, whereas that of conventional real-time PCR was $80 \mathrm{~min}$. The standard curve constructed from the amplification plots by droplet-real-time PCR using 10-fold dilutions of plasmids including a portion of the BRSV nucleocapsid protein $(\mathrm{N})$ gene $\left(10^{2}-10^{5}\right.$ copies $)$ was: $y=-3.5273 x+43.77$; that by conventional real-time PCR was: $y=-3.1795 x+44.922$ (Fig. 2A, 2B, 2C and 2D). Droplet-real-time PCR was as sensitive as conventional real-time PCR. Following dropletreal-time PCR, droplets were collected from the reaction tube and analyzed by gel electrophoresis. The amplified products were of the expected length, and no byproducts were observed (data not shown). All eight clinical samples (provided by the Nagano Prefectural Matsumoto Livestock Hygiene Service Center), which were positive for BRSV by conventional real-time PCR, were also positive using the droplet-real-time PCR (Fig. 2E).

Droplet-real-time PCR was able to detect BRSV within 10 min compared to $80 \mathrm{~min}$ for conventional real-time PCR (not including the time for RNA extraction). It has two heating blocks at different temperatures so that the reaction mixture can move by gravity to the incubator at the optimal temperature during rotation of the reaction tube (Fig. 1). Therefore, time to change the temperature of the reaction mixture is not required in the droplet-real-time PCR machine, but is required in the conventional real-time PCR machine with only one thermal incubator. These features of the droplet-real-time PCR machine enable high-speed reaction. The reaction conditions, which included thermal conditions, reagent concentrations and reaction buffer, were also important to shorten the reaction time. Therefore, droplet-real-time PCR markedly reduced the reaction time of RT-PCR while maintaining the same sensitivity as conventional real-time PCR (Fig. 2).

Other genetic diagnostic methods, such as the loop-mediated isothermal amplification (LAMP) [7], have recently become available. The reverse transcription (RT)-LAMP method involves simple procedures and has high sensitivity; however, this method requires $60 \mathrm{~min}$ for the reaction [10]. The present droplet-real-time PCR procedure was capable of detecting BRSV in a total time of less than $10 \mathrm{~min}$. Thus, it can play a critical role in rapid diagnosis of serious infectious diseases in domestic animals. Droplet-real-time PCR can also be applied to detect other pathogens, such as bovine herpesvirus-1 (BoHV-1, also known as bovine infectious rhinotracheitis virus), bovine parainfluenza type 3 (BPI3) [3,8] and highly pathogenic avian influenza viruses [11]. If genetic tests can be performed by droplet-real-time PCR on the farm without sending the samples to a laboratory, effective countermeasures can be quickly carried out in the early phase of a serious pathogen outbreak. This study demonstrated the potential application of droplet-real-time PCR to rapidly detect viral (microbial) RNA/DNA in clinical specimens. In addition, its additional advantages are smaller sample volume, cheaper reagent costs and shorter assay turnaround time compared to conventional real-time PCR. However, droplet-real-time PCR requires a DNA/RNA extraction process, and it will be necessary to develop a simple and rapid method to extract RNA/DNA to reduce the total time for diagnosis of disease-causing pathogens.

\section{REFERENCES}

1. Achenbach, J. E., Topliff, C. L., Vassilev, V. B., Donis, R. O., Eskridge, K. M. and Kelling, C. L. 2004. Detection and quantitation of bovine respiratory syncytial virus using real-time quantitative RT-PCR and quantitative competitive RT-PCR assays. $J$. Virol. Methods 121: 1-6. [Medline] [CrossRef]

2. Czuprynski, C. J. 2009. Host response to bovine respiratory pathogens. Anim. Health Res. Rev. 10: 141-143. [Medline] [CrossRef]

3. Ellis, J. A. 2001. The immunology of the bovine respiratory disease complex. Vet. Clin. North Am. Food Anim. Pract. 17: 535-550. [Medline]

4. Fulton, R. W. 2009. Bovine respiratory disease research (19832009). Anim. Health. Res. Rev. 10: 131-139. [Medline] [CrossRef]

5. Griffin, D. 1997. Economic impact associated with respiratory disease in beef cattle. Vet. Clin. North Am. Food Anim. Pract 13: 367-377. [Medline]

6. Heid, C. A., Stevens, J., Livak, K. J. and Williams, P. M. 1996. Real time quantitative PCR. Genome Res. 6: 986-994. [Medline] [CrossRef]

7. Notomi, T., Okayama, H., Masubuchi, H., Yonekawa, T., Watanabe, K., Amino, N. and Hase, T. 2000. Loop-mediated isothermal amplification of DNA. Nucleic Acids Res. 28: E63. [Medline] [CrossRef]

8. Pardon, B., De Bleecker, K., Dewulf, J., Callens, J., Boyen, F., Catry, B. and Deprez, P. 2011. Prevalence of respiratory pathogens in diseased, non-vaccinated, routinely medicated veal calves. Vet. Rec. 169: 278. [Medline] [CrossRef]

9. Thonur, L., Maley, M., Gilray, J., Crook, T., Laming, E., Turnbull, D., Nath, M. and Willoughby, K. 2012. One-step multiplex real time RT-PCR for the detection of bovine respiratory syncytial virus, bovine herpesvirus 1 and bovine parainfluenza virus 3 . BMC. Vet. Res. 8: 37. [Medline] [CrossRef]

10. Ushio, M., Yui, I., Yoshida, N., Fujino, M., Yonekawa, T., Ota, Y., Notomi, T. and Nakayama, T. 2005. Detection of respiratory syncytial virus genome by subgroups-A, B specific reverse transcription loop-mediated isothermal amplification (RT-LAMP). $J$. Med. Virol. 77: 121-127. [Medline] [CrossRef]

11. Uyeki, T. M. 2009. Human infection with highly pathogenic avian influenza A (H5N1) virus: review of clinical issues. Clin. Infect. Dis. 49: 279-290. [Medline] [CrossRef]

12. Valarcher, J. F. and Taylor, G. 2007. Bovine respiratory syncytial virus infection. Vet. Res. 38: 153-180. [Medline] [CrossRef]

13. van Elden, L. J., Nijhuis, M., Schipper, P., Schuurman, R. and van Loon, A. M. 2001. Simultaneous detection of influenza viruses A and B using real-time quantitative PCR. J. Clin. Microbiol. 39: 196-200. [Medline] [CrossRef]

14. Willoughby, K., Thomson, K., Maley, M., Gilray, J., Scholes, S., Howie, F., Caldow, G. and Nettleton, P. F. 2008. Development of a real time reverse transcriptase polymerase chain reaction for the detection of bovine respiratory syncytial virus in clinical samples and its comparison with immunohistochemistry and immunofluorescence antibody testing. Vet. Microbiol. 126: 264-270. [Medline] [CrossRef] 